\title{
Effects of windscape on three-dimensional foraging behaviour in a wide-ranging marine predator, the northern gannet
}

\author{
Jude V. Lane ${ }^{1, *}$, Dominick V. Spracklen ${ }^{2}$, Keith C. Hamer ${ }^{1}$ \\ ${ }^{1}$ School of Biology, University of Leeds, Leeds LS2 9JT, UK \\ ${ }^{2}$ School of Earth and Environment, University of Leeds, Leeds LS2 9JT, UK
}

\begin{abstract}
Marine birds are strongly exposed to weather conditions at sea but to date, few studies have investigated the influences of wind or rainfall on their time-activity budgets or foraging routines. Here, we used data from GPS and pressure loggers to investigate the effects of wind speed and direction and rainfall on the 3-dimensional foraging behaviour of gannets Morus bassanus breeding at Bass Rock, Scotland. We found that birds spent more time actively foraging during stronger winds, but there was no subsequent increase in overall trip duration because individuals compensated by decreasing the time they spent on the water during stronger winds. Birds returned more quickly from distant foraging grounds, and those encountering head winds spent less time on the water and so were able to compensate to some extent for an adverse effect of head winds on speed of travel over the return leg. These data strongly suggest that by reducing time spent on the water, birds were able to buffer trip durations against adverse effects of strong winds encountered during both commuting and active foraging. Birds also commuted at greater heights with increasing tail wind speed and at lower heights with increasing head wind speed, potentially providing an additional behavioural buffer against the adverse effects of strong head winds during foraging trips. There was no discernible effect of rain on foraging, but the behavioural flexibility recorded here is likely to be critical to maintaining nest attendance patterns and food provisioning rates of chicks across variable environmental conditions encountered at sea.
\end{abstract}

KEY WORDS: Foraging behaviour - GPS tracking - Northern gannet • Morus bassanus . Wind speed · Rainfall · Flight height

\section{INTRODUCTION}

Foraging behaviour is a large part of the daily routines of many species and an essential link between prey availability and predator reproductive success. For central-place foraging species, including many birds, a key issue in this context is the extent of behavioural flexibility in response to changing environmental conditions encountered during trips, especially when parents need to travel long distances to obtain prey (Tarroux et al. 2016, Kokubun et al. 2018). Wind is a major component of the environmental conditions experienced by birds (Hernández-Pliego et al. 2017, La Sorte \& Fink 2017), and increases in mean wind speeds and storm frequencies are predicted to

\footnotetext{
${ }^{*}$ Corresponding author: j.lane@leeds.ac.uk
}

occur as a result of anthropogenic climate change, particularly in mid-latitudes (McInnes et al. 2011, Young et al. 2011), along with increases in the frequency and intensity of extreme weather events (Coumou et al. 2015). Yet while research on the biological impacts of global climate change has focused extensively on the effects of changes in temperature and rainfall (Terraube et al. 2017, Zuckerberg et al. 2018), impacts of changing wind conditions have received much less attention (Elliott et al. 2014).

Marine birds are particularly exposed to wind conditions while foraging at sea and during commutes between terrestrial breeding sites and marine foraging grounds. Wind also influences wave patterns and turbulence (Salisbury et al. 2013, Albert et al. 2016),

() The authors 2019. Open Access under Creative Commons by Attribution Licence. Use, distribution and reproduction are unrestricted. Authors and original publication must be credited. 
which can alter the vertical distribution of forage fish in the water column and make them more difficult for surface-feeding and shallow-diving birds to locate and pursue (Konarzewski \& Taylor 1989, Finney et al. 1999, Baptist \& Leopold 2010, Parker-Stetter et al. 2016), while adverse winds may also reduce the speed with which parents can return to feed their offspring and relieve their partner at the nest. Many seabirds forage over large areas of ocean, so how they are affected by wind conditions encountered at sea may thus have important consequences for trip durations, nest attendance patterns and chick provisioning rates. Yet while a number of recent studies have examined changes in flight behaviour and energy expenditure in relation to wind conditions (Kogure et al. 2016, Gibb et al. 2017, Goto et al. 2017, Shepard et al. 2019), impacts on time-activity budgets and overall foraging routines have rarely been examined (Lewis et al. 2015).

Wind conditions also influence flight heights of birds (Krüger \& Garthe 2001, Villegas-Patraca \& Herrera-Alsina 2015, Tarroux et al. 2016). Over both land and open water, flying lower into head winds allows birds to take advantage of wind shear, where wind speed may be reduced by $\sim 15-20 \%$ at heights below $4 \mathrm{~m}$, while flying less than $1.5 \times$ wingspan above the surface also allows birds to utilise ground effect, where lift is increased and aerodynamic drag is decreased as a result of the ground interrupting wingtip vortices and downwash behind the wing (Rayner 1991, Finn et al. 2012). Hence flying close to the surface reduces flight costs when flying into head winds while flying higher with tail winds enables faster and more efficient flight (Liechti et al. 2000, Krüger \& Garthe 2001, Green 2004). Adjustments in flight height may thus be an important component of seabirds' responses to changing wind conditions at sea, but there are few previous data to address this question. For seabirds that exploit prey close to the water surface, foraging efficiency may also be influenced by rainfall, but the effects of rain on foraging behaviour are poorly understood (Pistorius et al. 2015).

Northern gannets Morus bassanus (hereafter gannets) are plunge-diving predators that obtain most of their prey within $10 \mathrm{~m}$ of the water surface (Lewis et al. 2002, Cleasby et al. 2015a). During chick-rearing, adults make foraging trips lasting up to $1 \mathrm{~d}$ or longer and covering $10 \mathrm{~s}$ to $100 \mathrm{~s}$ of $\mathrm{km}$ (Hamer et al. 2000, Wakefield et al. 2013). Flight comprises $~ 50 \%$ of total trip time, and the dive rate of birds per daylight hour is apparently unrelated to trip duration (Lewis et al. 2004). Birds can reduce time away from the nest by returning to the colony at greater speeds from more distant foraging locations, but speeds decrease for the furthest destinations, probably due to constraints on energy expenditure during sustained flight (Hamer et al. 2007). Energy expenditure in flight is also strongly affected by wind speed and direction (Amélineau et al. 2014), but it is not clear how wind conditions affect birds' average speed of travel at sea or to what extent they can adjust their behaviour to reduce potential impacts of adverse wind conditions on time away from the nest. In addition, birds fly higher when actively foraging than when commuting between the nest site and foraging sites (Cleasby et al. 2015b), but it is not known how wind conditions or rainfall affect flight heights during commuting or foraging. Here, we investigated variation in the 3-dimensional foraging behaviour of gannets in response to weather conditions in the North Sea. We first examined how wind speed and direction and rainfall affect birds' foraging trip durations and time-activity budgets at sea. We then assessed how wind conditions affect birds' speed of travel and to what extent birds adjust their time-activity budgets to reduce the impact of adverse wind conditions on their rate of return to the nest from distant foraging sites. We next examined the influence of wind and rainfall on the flight heights of birds during commuting and active foraging.

\section{MATERIALS AND METHODS}

\subsection{Study site and data collection}

Fieldwork took place at Bass Rock, UK $\left(56^{\circ} 6^{\prime} \mathrm{N}\right.$, $2^{\circ} 36^{\prime} \mathrm{W}$ ) between mid-June and mid-August of 2015-2017. In total, 63 adult gannets with chicks were caught at the nest using a $6 \mathrm{~m}$ telescopic pole fitted with a metal noose or hook. Each bird was fitted with a metal British Trust for Ornithology ring and a coloured plastic ring with a unique alphanumeric code for easy identification at the nest site. We then recorded body mass to the nearest $10 \mathrm{~g}$ using an electronic scale. Each bird had a GPS logger (igotUGT600, Mobile Action Technology) attached to the upper side of the central tail feathers and a logger recording atmospheric pressure and temperature (MSR-145W, MSR Electronics) attached to the central tail feather, on the underside to reduce Bernoulli effects during take-off from the water. GPS loggers weighed $30 \mathrm{~g}$ and recorded location at 2 min intervals; pressure loggers weighed $18 \mathrm{~g}$ and recorded at $1 \mathrm{~Hz}$; both were attached using Tesa ${ }^{\odot}$ tape. All sampled birds were recaptured after 7-14 d to retrieve loggers. Handling time of birds at both deployment 
and recapture was no longer than $15 \mathrm{~min}$, and on both occasions birds returned to their chick almost immediately and resumed normal behaviour. The combined weight of loggers was $<2 \%$ of body mass, which was well within recommended guidelines (Phillips et al. 2003); previous studies at this colony recorded that such deployments had no discernible impact on trip duration or body mass (Hamer et al. 2007, 2009, Cleasby et al. 2015a).

\subsection{Trip analysis}

For each foraging trip we determined the duration $(\mathrm{h})$, total distance travelled $(\mathrm{km})$, maximum distance $(\mathrm{km})$ on a direct bearing from the colony and departure angle (degrees) from the colony (an average of the first 5 bearings $>10 \mathrm{~km}$ from the colony; Patrick et al. 2014). We used the furthest location from the colony to distinguish between outbound and inbound stages of each trip; inbound distance was the total distance travelled from the furthest location back to the colony. We also calculated the direction of travel throughout each trip as the bearing between successive locations. In addition, speeds and turning angles derived from GPS data were used to classify the behaviour of birds at sea into 3 categories: commuting, characterised by long step lengths and small turning angles; active foraging, characterised by short step lengths and large turning angles; and time spent on the water, characterised by short step lengths and small turning angles (Wakefield et al. 2013, Amélineau et al. 2014, Grecian et al. 2018). Validation of these discrimination criteria against a separate sample of birds equipped with GPS loggers and timedepth recorders (TDRs) showed that, within individuals, $99 \%$ of GPS locations occurring within 10 min of dives detected using TDRs were classified as foraging (Wakefield et al. 2013).

\subsection{Weather conditions}

We obtained data on wind speed and direction and rainfall during foraging trips from the ERA-Interim reanalysis data set produced by the European Centre for Medium-Range Weather Forecasts (ECMWF) (6hourly data at $0.125 \times 0.125^{\circ}$ or approximately $8 \times$ $8 \mathrm{~km}$ resolution) (Dee et al. 2011). For every bird location at sea, we extracted the nearest data in time and space for rainfall $\left(\mathrm{mm} \mathrm{h}^{-1}\right)$ and $10 \mathrm{~m}$ zonal (westeast) and meridional (south-north) wind components at $10 \mathrm{~m}$ a.s.l. (max. distance: $4 \mathrm{~km}$; max. time differ- ence: $3 \mathrm{~h})$. We then calculated wind speed $\left(\mathrm{m} \mathrm{s}^{-1}\right)$ and direction $\left({ }^{\circ}\right)$ using Eqs. 1 and 2, respectively:

$$
\begin{gathered}
W s=\sqrt{U W^{2}+V W^{2}} \\
W_{V}=\frac{180}{\pi}(\operatorname{atan}(V W, U W))
\end{gathered}
$$

where $W_{S}=$ wind speed, $U_{W}=$ zonal wind component, $V W=$ meridional wind component and $W_{V}=$ meteorological wind direction.

Following Amélineau et al. (2014), we used birdwind angle (BWA) to characterise the relationship between wind direction and the bird's direction of travel. Absolute values of $0-45^{\circ}$ (i.e. up to $45^{\circ}$ to left or right of bird's heading) were categorised as head winds, $45-135^{\circ}$ as cross winds and $135-180^{\circ}$ as tail winds.

\subsection{Flight height estimation}

Following Cleasby et al. (2015b), we used the barometric equation to estimate the height of the bird $(h)$ above sea level:

$$
h=\frac{K T}{m g} \ln \left(\frac{P}{P_{0}}\right)
$$

where $P_{0}$ and $P$ are the atmospheric pressures (Pa) at sea level and at height $h(\mathrm{~m})$ respectively; $K$ is the universal gas constant for air $\left(8.31432 \mathrm{~N} \mathrm{~m} \mathrm{~mol}^{-1} \mathrm{~K}^{-1}\right)$; $m$ is the molar mass of air $\left(0.0289644 \mathrm{~kg} \mathrm{~mol}^{-1}\right) ; g$ is the acceleration due to gravity $\left(9.80665 \mathrm{~m} \mathrm{~s}^{-2}\right)$; and $T$ is the temperature $(\mathrm{K})$ of the atmosphere between $h_{0}$ and $h$ (see Supplement 1 at www.int-res.com/ articles/suppl/m628p183_supp.pdf). We obtained calibration pressures $\left(P_{0}\right)$ when birds spent time on the water (Cleasby et al. 2015b) and we accounted for spatial and temporal changes in atmospheric pressure during long periods of sustained flight by adjusting calibration pressures throughout the duration of each flight bout using the ERA-Interim reanalysis sea surface pressure data set (6-hourly data at $0.125 \times$ $0.125^{\circ}$ or approximately $8 \times 8 \mathrm{~km}$ resolution) (Dee et al. 2011).

\subsection{Statistical analysis}

All analyses were conducted using R v.3.2.2 (R Core Team 2016). We used linear mixed-effects models (LMMs) fitted using the R package 'nlme' (Pinheiro et al. 2018) to examine how wind speed, direction and rainfall affected trip durations and the proportion of each trip spent actively foraging, commuting and on 
the water. Our rationale here was that birds show pronounced individual foraging site fidelity during chickrearing (Hamer et al. 2001, Wakefield et al. 2015), so the distance travelled on each trip was modelled as a predictor variable that, together with different weather variables, could potentially affect both total trip duration and the proportion of time spent in different activities per trip. We included a mean value for wind speed, wind direction and rainfall per hour for each trip and we included year as a fixed effect to account for differences in trip parameters between years. We also included bird identity as a random effect to control for repeated measures due to multiple trips per bird. Continuous predictor variables were normalised to increase the interpretability of parameter estimates (Schielzeth 2010), and we tested for collinearity between predictor variables to ensure this would not cause difficulties for determining true relationships (Freckleton 2011).

In view of the large number of predictor variables and potential interactions, model simplification and selection were performed using a multi-model inference approach based on the methods and recommendations of Grueber et al. (2011), using the 'MuMIn' package (Bartoń 2015). A set of candidate models was first identified for each response variable, with all possible subsets of predictor variables and interactions considered. Support for different candidate models was then assessed using Akaike's information criterion adjusted for small sample size $\left(\mathrm{AIC}_{\mathrm{c}}\right)$ and Akaike weights. Models with the greatest raw $\mathrm{AIC}_{\mathrm{C}}$ weight and a $\Delta \mathrm{AIC}_{\mathrm{C}}>2$ from the next ranked model were considered to have the best model fit (Burnham \& Anderson 2002), but where there was uncertainty over the top model, parameter estimates and the relative importance of each parameter were averaged across selected models, with test statistics and p-values extracted using MuMln.

To assess how wind conditions influenced flight speed and whether or not gannets adjusted their behaviour to compensate, we first used a LMM to examine how mean wind speed and direction affected mean ground speed during periods of commuting flight. This analysis included foraging trip identity nested within bird identity as a random effect, to account for repeated measures within each foraging trip and multiple trips per bird. A temporal autocorrelation structure was also included to control for non-independence of successive data within each trip. We then used LMMs to examine how median wind speed and direction affected the average speed of travel during daylight hours and the proportion of day time spent on the water during the return leg of each trip. Travel speeds were right-skewed and were therefore square-root transformed prior to analysis. Each model also included bird identity as a random effect to control for multiple trips per bird. We ran 3 models for both travel speed and proportion of time on the water, to include all combinations of distance and distance ${ }^{2}$ to account for potential non-linear relationships (Hamer et al. 2007), and we then selected the best model using $\mathrm{AIC}_{\mathrm{C}}$ values.

To examine how wind and rainfall affected flight heights, we first used a LMM to compare the median heights of birds during each period of commuting and active foraging. Rainfall was the mean value during each period of flight. Wind direction was characterised from BWA and cross winds were excluded from the analysis. Foraging trip identity nested within bird identity was included as a random effect to account for repeated measures within each foraging trip and multiple trips per bird, and a temporal autocorrelation structure was included to control for non-independence of successive data within each trip. We then used a linear model (LM) to examine the influence of wind speed on flight heights. For this analysis, wind speeds were binned at $1 \mathrm{~m} \mathrm{~s}^{-1}$ intervals, with head winds having negative speeds and tail winds positive speeds, and a mean height was used for each wind speed interval. Heights were right-skewed and were therefore square-root transformed prior to calculating means. Some estimated flight heights were below $0 \mathrm{~m}$ and, following Cleasby et al. (2015b), these were retained in the analysis by adding the minimum estimated height (absolute value) to all cases to permit square root-transformation.

\section{RESULTS}

We acquired combined GPS and altitude data for 188 trips by 46 individuals (106 trips by 29 birds in 2015; 47 trips by 16 birds in 2016; 35 trips by 13 birds in 2017; data from 17 birds were incomplete). Most trips travelled northeast or southeast of the colony, with fewer travelling due east (Fig. 1). The prevailing wind direction was from the southwest (Fig. S1 in Supplement 2) and accordingly, birds spent most of their time in flight with cross winds and tail winds when commuting away from the colony, and with head winds and cross winds when returning to the colony (Fig. 2a,c). When actively foraging, however, birds spent significantly more time flying into the wind (mean \pm SD: $33 \pm 14 \%$ ) and less with the wind behind them $(18 \pm 10 \%)$ than expected by chance (Fig. 2b; $\chi_{2}^{2}=511.0, \mathrm{p}<0.0001$; birds frequently 


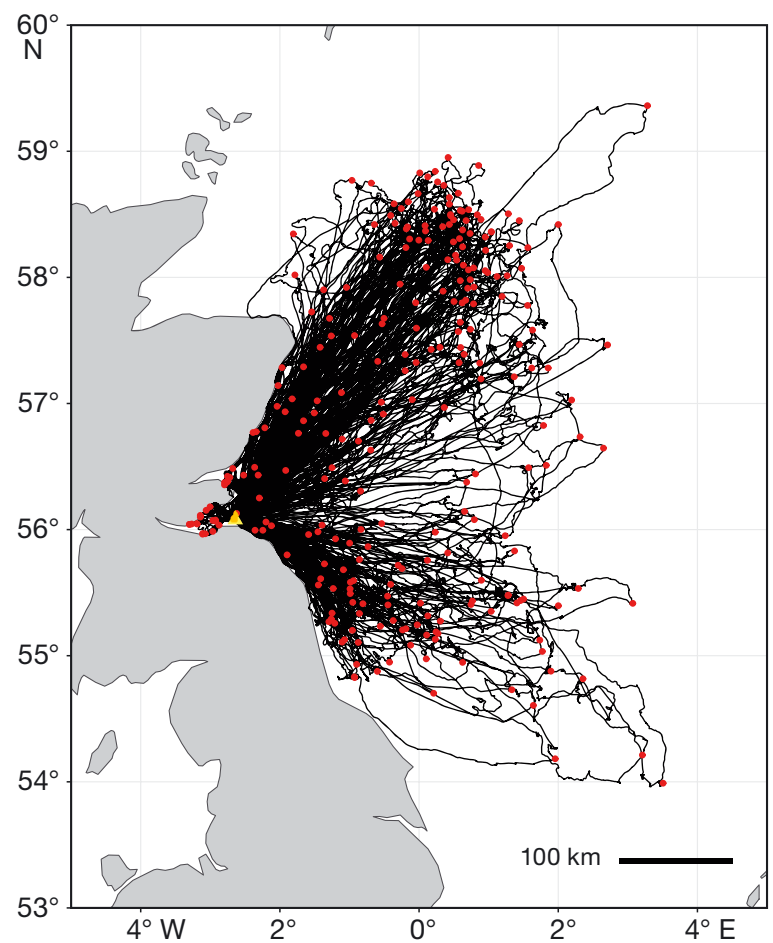

Fig. 1. Tracks of foraging trips $(n=263)$ by adult northern gannets rearing chicks at Bass Rock between mid-June and mid-August of 2015-2017. Red dots: maximum distance from the colony on each trip; yellow triangle: colony location

changed direction while actively foraging so would have been expected by chance to spend $25 \%$ of their time with head winds, $50 \%$ with cross winds and $25 \%$ with tail winds).

\subsection{Trip durations and time-activity budgets at sea}

The mean duration of foraging trips was $24.3 \pm$ $10.7 \mathrm{~h}$ (range: $1.5-70.3 \mathrm{~h}$ ). Both trip duration and the proportion of each trip spent commuting were significantly positively related to total distance travelled (Fig. $3 ; \mathrm{LMM}_{;} \chi_{1}^{2}=378.5, \mathrm{p}<0.001$ and $\chi_{1}^{2}=57.1, \mathrm{p}<$ 0.001 , respectively) but no weather variables improved either model $\left(\Delta \mathrm{AIC}_{\mathrm{c}}>5\right.$ for trip duration, $>2$ for proportion of trip commuting; $\mathrm{AIC}_{\mathrm{c}}$ weight dropped from $>0.8$ to $<0.1$ and from $>0.5$ to $<0.2$, respectively; Table 1). The proportion of time spent actively foraging per trip increased significantly with increasing wind speed (Fig. 3c; $\chi_{1}^{2}=14.6, p<0.001$ ) but the model was not improved by including any other variable $\left(\Delta \mathrm{AIC}_{\mathrm{c}}>5\right.$ in each case; Table 1$)$. There was no clear top model for the proportion of daylight hours spent on the water, but model averaging of the top 3 models (i.e. those with $\Delta \mathrm{AIC}_{\mathrm{c}}<2$; Table 1) found distance travelled per trip and wind speed to be the

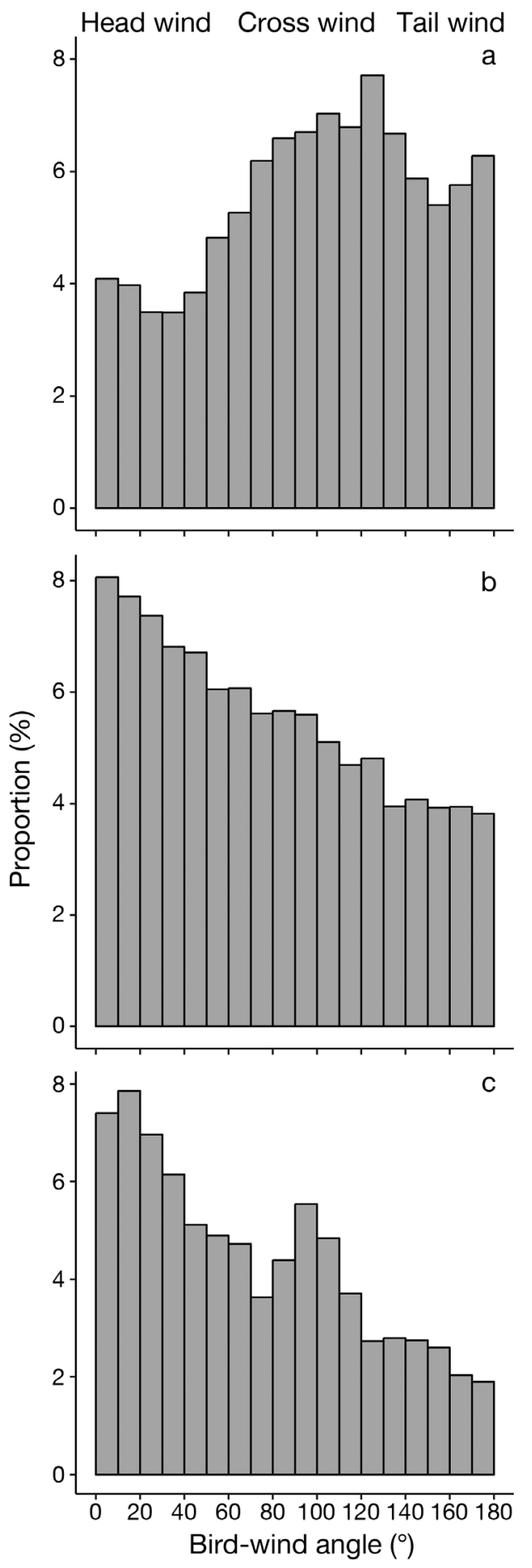

Fig. 2. Frequency distribution of bird-wind angles for GPS locations of northern gannets during (a) outbound commuting ( $\mathrm{n}=19238$ locations), (b) active foraging ( $\mathrm{n}=20446)$ and (c) inbound commuting $(\mathrm{n}=21233)$

most significant factors (Table 2), indicating that the proportion of time on the water decreased as distance travelled increased and with increasing wind speed (Figs. 3d \& 4). 

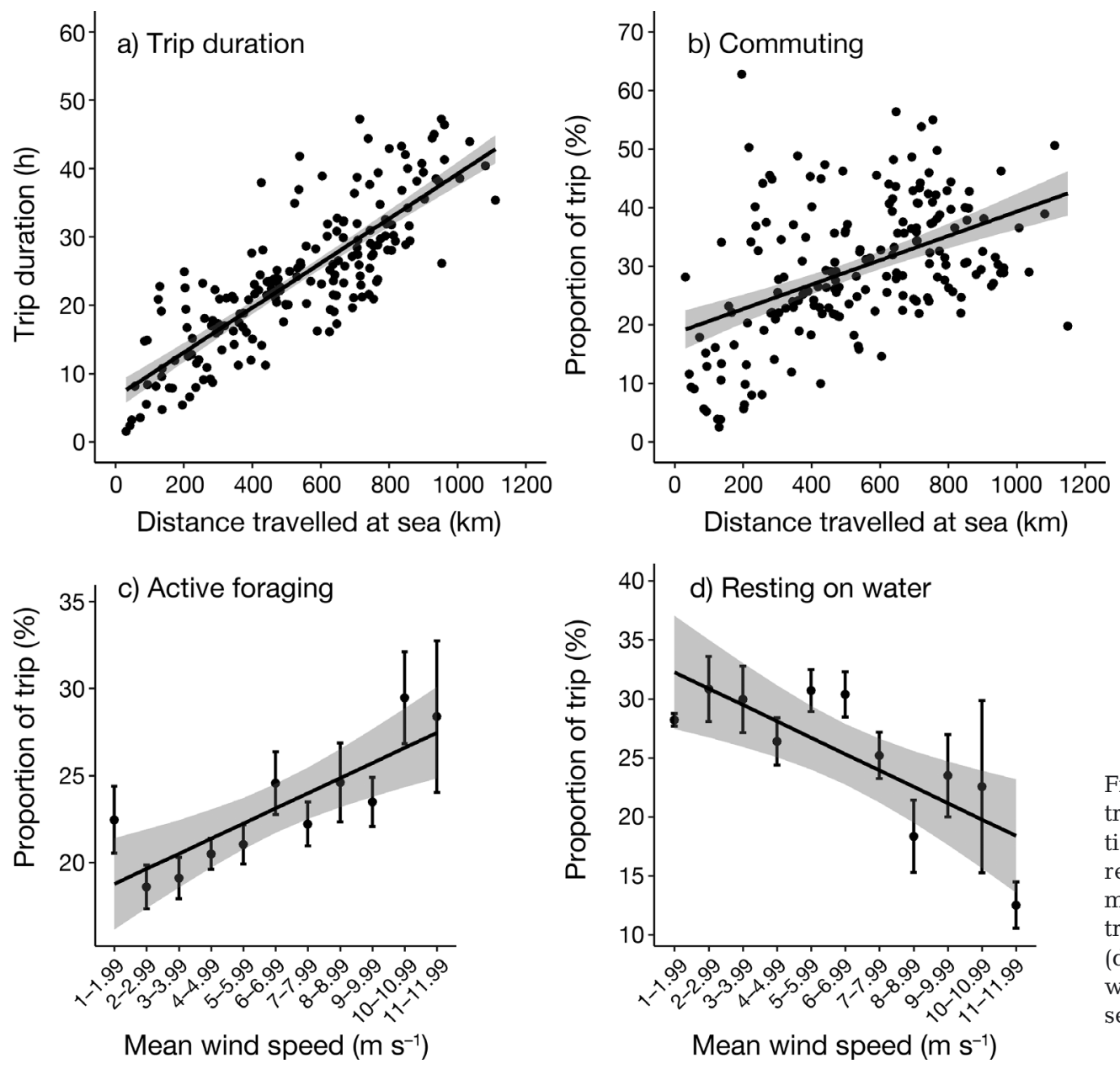

Fig. 3. Northern gannet (a) trip duration and (b) proportion of the trip commuting in relation to total trip distance; mean \pm SE proportion of the trip (c) actively foraging and (d) resting in relation to mean wind speed encountered at sea. Line (shading): model prediction $(95 \% \mathrm{CI})$

\subsection{Flight speeds and rates of return to the nest}

During periods of commuting, whether outbound or inbound, ground speeds were faster with a tail wind component than with a head wind component $\left(\mathrm{LMM} ; \chi_{2}^{2}=301.5, \mathrm{p}<0.001 ;\right.$ mean $\pm \mathrm{SD}: 17.5 \pm 3.4$ and $12.6 \pm 2.0 \mathrm{~m} \mathrm{~s}^{-1}$, respectively). As expected, ground speeds increased as the tail wind component increased and the head wind component decreased (Fig. $5 \mathrm{a} ; \chi_{1}^{2}=278.67, \mathrm{p}<0.001$ ). The average speed of travel over the return leg of a trip was significantly related to both distance from the colony and distance $^{2}\left(\mathrm{LMM} ; \chi_{1}^{2}=14.0, \mathrm{p}<0.001\right.$ and $\chi_{1}^{2}=5.9, \mathrm{p}<$ 0.05 , respectiv ely) indicating a non-linear relations hip with distance, while the best-performing model according to $\mathrm{AIC}_{\mathrm{C}}$ also included wind speed and direction (Table 3): average travel speed increased with increasing distance from the colony up to 100$200 \mathrm{~km}$ (fastest for birds returning with a tail wind, slowest for those returning into a head wind), beyond which the relationship levelled off (Fig. 5b). Time spent on the water during the return leg of a trip was also significantly related to inbound distance travelled $\left(\chi_{1}^{2}=5.9, p<0.05\right)$ with the best-supported model also including distance ${ }^{2}$ and wind speed and direction (Table 3). For return legs up to 100-200 km, time on the water decreased with increasing distance and was greatest for birds returning with a tail wind and least for those returning into a head wind (Fig. 5c).

\subsection{Flight heights}

Median flight height was significantly lower during periods of commuting than active foraging (LMM; $\chi_{1}^{2}=4.75, \mathrm{p}<0.05$; Table 4) but was unaffected by rainfall. Birds also flew lower into head winds than with tail winds when commuting $\left(\chi_{1}^{2}=37.6, \mathrm{p}<\right.$ 0.001 ) but not while actively foraging, when median height was $\sim 28 \mathrm{~m}$ irrespective of wind direction (Table 4). In addition, commuting flight heights increased with increasing tail wind speed and decreased as head wind speed increased (LM; $F_{1,18}=$ 
Table 1. Top model sets for estimating effects of weather parameters on different components of northern gannet behaviour during foraging trips. LogLik: log-likeli hood $\mathrm{AIC}_{\mathrm{c}}$ : Akaike's information criterion corrected for small sample size

\begin{tabular}{|c|c|c|c|c|c|c|}
\hline Rank & Model & df & LogLik & $\mathrm{AIC}_{\mathrm{c}}$ & $\Delta \mathrm{AIC}_{\mathrm{c}}$ & $\begin{array}{c}\mathrm{AIC}_{\mathrm{c}} \\
\text { weight }\end{array}$ \\
\hline \multicolumn{7}{|c|}{ Trip duration } \\
\hline 1 & Trip distance & 5 & -185.87 & 382.1 & 0.00 & 0.827 \\
\hline 2 & Trip distance + rainfall & 6 & -187.55 & 387.6 & 5.48 & 0.053 \\
\hline 3 & Trip distance + wind speed & 6 & -187.91 & 388.3 & 6.21 & 0.037 \\
\hline 4 & Trip distance + wind direction & 6 & -187.98 & 388.4 & 6.34 & 0.035 \\
\hline 5 & Trip distance + year & 7 & -186.93 & 388.5 & 6.41 & 0.034 \\
\hline \multirow[t]{2}{*}{6} & Trip distance + rainfall + year & 8 & -188.49 & 393.8 & 11.71 & 0.002 \\
\hline & Null model & 4 & -293.45 & 595.1 & 213.04 & 0.000 \\
\hline \multicolumn{7}{|c|}{ Proportion of trip commuting } \\
\hline 1 & Trip distance & 5 & -265.13 & 540.6 & 0.00 & 0.518 \\
\hline 2 & Trip distance + rainfall & 6 & -265.11 & 542.7 & 2.10 & 0.181 \\
\hline 3 & Trip distance + year & 7 & -264.57 & 543.8 & 3.19 & 0.105 \\
\hline 4 & Trip distance + wind direction & 6 & -266.51 & 545.5 & 4.90 & 0.045 \\
\hline 5 & Trip distance + rainfall + year & 8 & -264.40 & 545.6 & 5.04 & 0.042 \\
\hline \multirow[t]{2}{*}{6} & Trip distance + wind speed & 6 & -266.76 & 546.0 & 5.40 & 0.035 \\
\hline & Null model & 4 & -288.37 & 585.0 & 44.36 & 0.000 \\
\hline \multicolumn{7}{|c|}{ Proportion of trip actively foraging } \\
\hline 1 & Wind speed & 5 & -187.43 & 385.2 & 0.00 & 0.825 \\
\hline 2 & Wind speed + wind direction & 6 & -189.34 & 391.2 & 5.97 & 0.042 \\
\hline 3 & Wind speed + rainfall & 6 & -189.42 & 391.3 & 6.13 & 0.039 \\
\hline 4 & Wind speed + trip distance & 6 & -189.48 & 391.4 & 6.23 & 0.037 \\
\hline 5 & Wind speed + year & 7 & -188.86 & 392.4 & 7.16 & 0.023 \\
\hline 6 & Null model & 4 & -192.40 & 393.0 & 7.82 & 0.017 \\
\hline \multicolumn{7}{|c|}{ Proportion of trip on the water } \\
\hline 1 & Trip distance + wind speed + year & 8 & -247.53 & 511.9 & 0.00 & 0.418 \\
\hline 2 & $\begin{array}{l}\text { Trip distance + wind speed + rainfall } \\
+ \text { year }\end{array}$ & 9 & -247.37 & 513.8 & 1.89 & 0.162 \\
\hline 3 & Trip distance + wind speed & 6 & -250.70 & 513.9 & 1.99 & 0.154 \\
\hline 4 & $\begin{array}{l}\text { Trip distance + wind speed + } \\
\text { wind direction + year }\end{array}$ & 9 & -247.97 & 515.0 & 3.09 & 0.089 \\
\hline 5 & $\begin{array}{l}\text { Trip distance }+ \text { wind speed }+ \text { wind } \\
\text { direction }+ \text { year }+ \text { wind speed } \times \\
\text { wind direction }\end{array}$ & 10 & -247.76 & 516.8 & 4.91 & 0.036 \\
\hline \multirow[t]{2}{*}{6} & Trip distance + wind speed + rainfall & 7 & -251.13 & 516.9 & 5.02 & 0.034 \\
\hline & Null model & 4 & -270.90 & 550.0 & 38.15 & 0.000 \\
\hline
\end{tabular}

\section{DISCUSSION}

Wind conditions encountered at sea have complex effects on birds' time-activity and energy budgets, with potentially contrasting effects on the time and energy spent commuting between the colony and distant foraging sites and during periods of active foraging. For black-legged kittiwakes Rissa tridactyla and little auks Alle alle, which are purely flapping species, energy expenditure increased and food-provisioning rates of chicks decreased during strong winds (Gabrielsen et al. 1987, 1991, Konarzewski \& Taylor 1989, Christensen-Dalsgaard et al. 2018). In contrast, however, northern fulmars Fulmarus glacialis, which are flapgliders, had lower energy expenditure due to a lower wing beat frequency during stronger winds (Furness \& Bryant 1996), while higher average wind speeds led to enhanced foraging efficiency and breeding success in wandering albatrosses Diomedea exulans (Weimerskirch et al. 2012). For northern gannets, we found that while wind speed and direction had strong effects on the speed of travel between the colony and distant foraging sites, there was no effect on the proportion of each trip spent commuting, probably be-

Table 2. Model-averaged estimates for factors affecting the proportion of each trip spent resting on the water by northern gannets during daylight hours; $\mathrm{n}=3$ models

\begin{tabular}{|lrccc|}
\hline Parameter & Estimate $\begin{array}{c}\text { Confidence } \\
\text { interval }\end{array}$ & $p$ & $\begin{array}{c}\text { Relative } \\
\text { importance }\end{array}$ \\
\hline Trip distance & 5.13 & -0.56 to -0.27 & $<0.001$ & 1.0 \\
Wind speed & -0.42 & -0.42 to -0.43 & $<0.001$ & 1.0 \\
Rainfall & 0.13 & -0.01 to 0.27 & 0.06 & 0.22 \\
Year (2016) & 0.06 & -0.26 to 0.40 & 0.69 & 0.79 \\
Year (2017) & 0.56 & 0.19 to 0.92 & 0.002 & 0.79 \\
\hline
\end{tabular}

17.9, $\mathrm{p}<0.001$; Fig. 6 ; slope $[ \pm \mathrm{SE}]=1.06 \pm 0.25, \mathrm{R}^{2}=$ 0.47 ) whereas there was no discernible effect of wind speed on heights during active foraging (slope $=$ $-0.17 \pm 0.25, \mathrm{R}^{2}=0.02$ ). cause with a constant wind direction, birds would encounter both head and tail winds over the outward and return portions of a trip. Birds spent more time flying into head winds during active foraging than when commuting, probably to provide additional lift and reduce ground speed to aid detection of prey (Machovsky-Capuska et al. 2012, Amélineau et al. 2014). However, birds also spent more time actively foraging during stronger winds, probably because strong winds disrupted the water surface (Sundarabalan et al. 2016), reducing prey visibility and hence potentially leading to both more time spent locating prey and a greater number of dives to capture prey as a result of lower success rates per dive (Finney et al. 1999, Elliott et al. 2014, Pistorius et al. 2015). Frequent dives and associated take-offs from the water surface are 

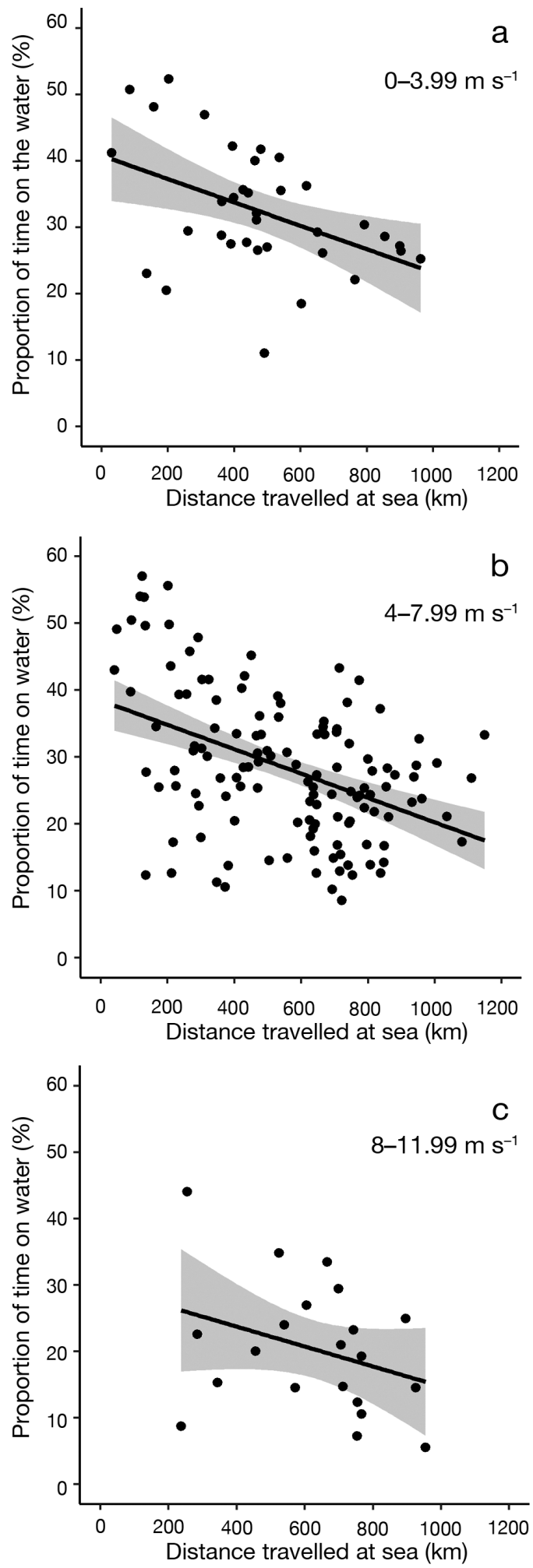

Fig. 4. Proportion of daylight hours spent on the water by northern gannets in relation to distance travelled per trip and mean wind speed encountered during the trip. Lines (with 95\% CI) plotted using model-averaged estimates for each predictor variable (see Table 2)
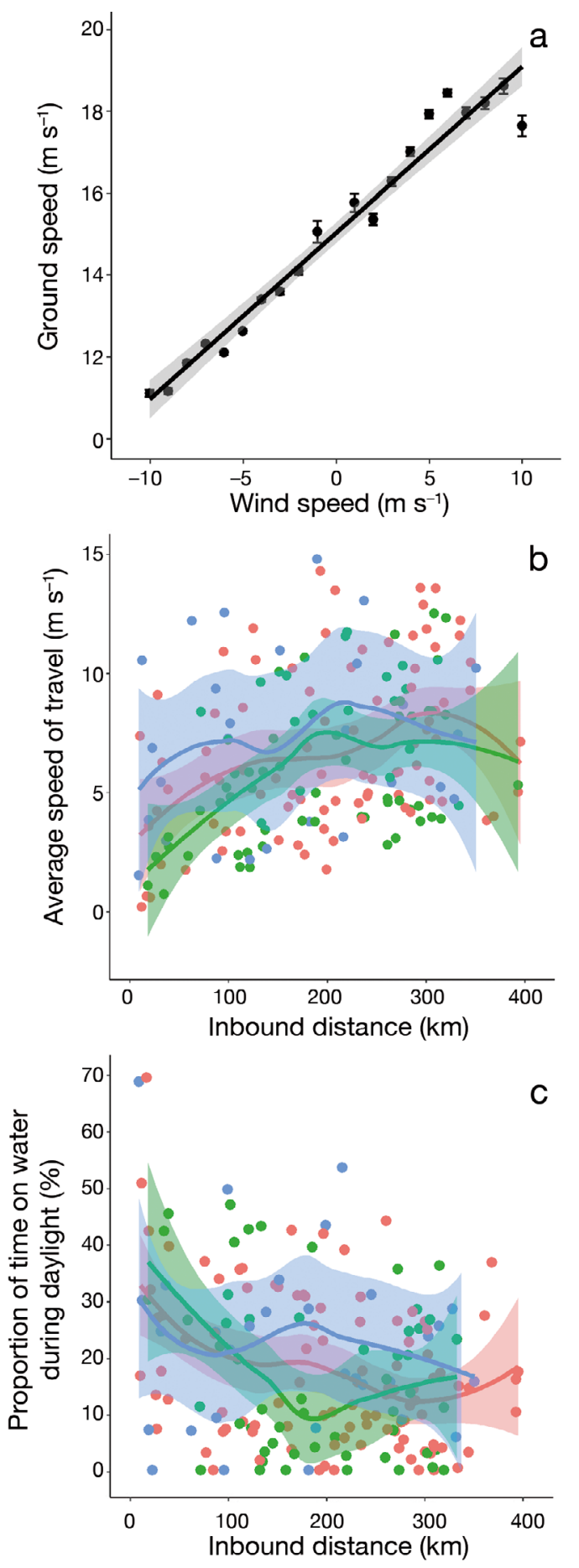

Fig. 5. (a) Mean ( \pm SE) ground speeds of commuting northern gannets in relation to the mean wind speed at $10 \mathrm{~m}$ a.s.l. over a trip for tail winds (speed $>0$ ) and head winds (speed $<0$ ). (b) Average speed of travel and (c) proportion of daylight hours on the water during the return leg of foraging trips in relation to distance $(\mathrm{km})$ for different bird-wind angles. Lines: linear model predictions in (a) and predictions estimated with loess function in R (blue: tail winds; red: cross winds; green: head winds) in $(b, c)$. Shaded areas: $95 \%$ CI.

Based on 188 foraging trips 
Table 3. Top model sets for estimating effects of different variables on average speed of travel and proportion of time resting on the water during the return leg of each trip by northern gannets. LogLik: log-likelihood; $\mathrm{AIC}_{\mathrm{c}}$ : Akaike's information criterion corrected for small sample size

\begin{tabular}{|c|c|c|c|c|}
\hline Model & $\mathrm{df}$ & LogLik & $\mathrm{AIC}_{\mathrm{c}}$ & $\Delta \mathrm{AIC}_{\mathrm{C}}$ \\
\hline \multicolumn{5}{|l|}{ Speed } \\
\hline $\begin{array}{l}\text { Distance }+ \text { distance }{ }^{2}+\text { wind speed } \\
+ \text { wind direction }\end{array}$ & 7 & -182.16 & 379.0 & 0 \\
\hline Distance + wind speed + wind direction & 6 & -184.28 & 381.0 & 2.0 \\
\hline Distance $^{2}+$ wind speed + wind direction & 6 & -187.94 & 388.3 & 9.3 \\
\hline \multicolumn{5}{|l|}{ Resting } \\
\hline $\begin{array}{l}\text { Distance + distance }{ }^{2}+\text { wind speed } \\
+ \text { wind direction }\end{array}$ & 7 & -376.47 & 767.6 & 0 \\
\hline Distance + wind speed + wind direction & 6 & -378.48 & 769.4 & 1.8 \\
\hline Distance $^{2}+$ wind speed + wind direction & 6 & -379.72 & 771.9 & 4.3 \\
\hline
\end{tabular}

Table 4. Flight heights of northern gannets during commuting and active foraging with head and tail winds. IQR: interquartile range

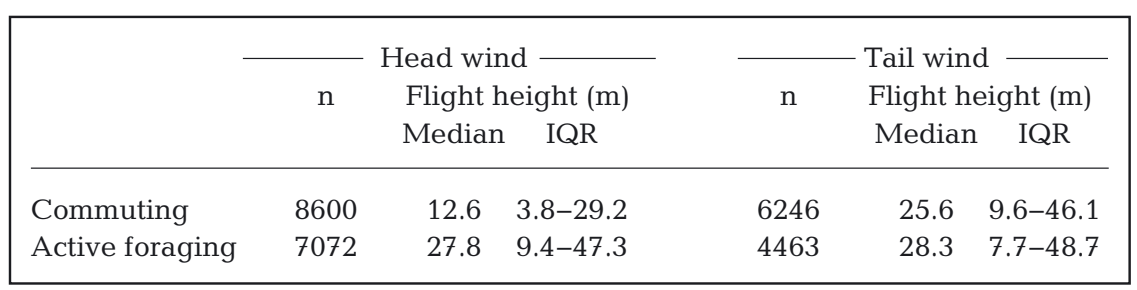

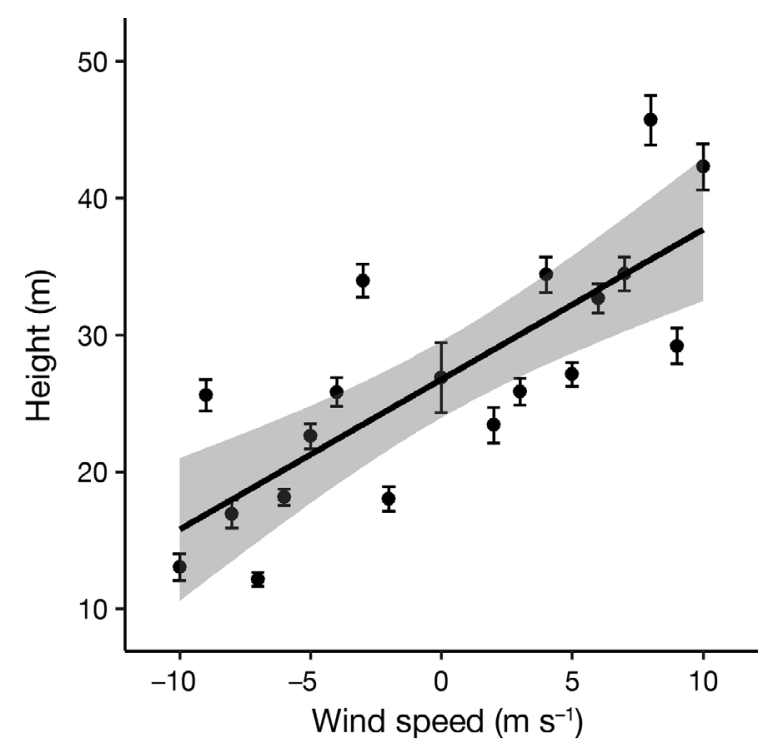

Fig. 6. Mean $( \pm \mathrm{SE})$ flight heights of commuting northern gannets in relation to the mean wind speed at $10 \mathrm{~m}$ a.s.l. over a trip for tail winds (speed $>0$ ) and head winds (speed $<0$ ). Line (shading): linear model prediction $(95 \% \mathrm{CI})$

energetically expensive (Sakamoto et al. 2013), so a greater time spent actively foraging in stronger winds may explain why, while energy spent in commuting flight decreased with increasing wind speed in northern gannets (Amélineau et al. 2014), overall energy expenditure during trips increased with increasing wind speed in closely related Cape gannets $M$. capensis (Mullers et al. 2009).

We found that the increase in time spent foraging as wind speed increased did not result in any increase in overall trip duration, because birds compensated by decreasing the time they spent on the water during stronger winds, presumably reflecting a benefit in returning quickly to feed dependent offspring and relieve the partner at the nest. We also found that adults returned to Bass Rock at higher speeds from more distant foraging locations up to $\sim 200 \mathrm{~km}$ from the colony, a similar pattern to that recorded by Hamer et al. (2007), who also found that speeds decreased for the furthest destinations, probably due to constraints on energy expenditure during sustained flapping flight. In keeping with this notion, we found that the increase in average speed of travel for distances up to $\sim 200 \mathrm{~km}$ was accompanied by a decrease in the proportion of time on the water, particularly for birds flying into head winds, with an asymptote in speed of travel corresponding with a levelling off in time on the water beyond this distance. These data strongly suggest that by reducing time spent on the water, birds were able to buffer trip durations against adverse effects of strong winds encountered both while commuting and during active foraging.

In addition to altering time spent on the water during trips, birds also adjusted their flight heights in relation to wind speed and direction. The higher proportion of commuting flight at low elevations into head winds compared with tail winds was similar to that recorded in a wide range of species during migration (Krüger \& Garthe 2001) and supports the notion that individuals can make use of both wind shear and ground effect to ameliorate the impacts of strong head winds on ground speed and energy expenditure (Finn et al. 2012, Tarroux et al. 2016). During the breeding season, this flexibility in commuting flight height may provide an additional behavioural buffer against the adverse effects of strong head winds during foraging trips.

Oceanic winds affect the prey fields of marine predators by altering their ability to access, detect 
and capture prey, acting as an additional dimension in their $\mathrm{N}$-dimensional niche space (Raymond et al. 2010, Wilson et al. 2011, Weimerskirch et al. 2012). While gannets were able to buffer adverse effects of strong winds by reducing time spent drifting on water during trips and also by altering their flight heights in relation to wind conditions, other species may have different behavioural responses. For instance, Brünnich's guillemots Uria lomvia and blacklegged kittiwakes buffered the adverse effect of high winds on food-provisioning rates of chicks by switching to other food sources during windy days or increasing food delivery rates when weather improved (Elliott et al. 2014). Such behavioural flexibility is likely to be critical to maintaining fitness across variable environmental conditions encountered at sea, and parallels that recorded at an annual time-scale in a number of species in response to climate-related variation in prey abundance and availability (Grémillet et al. 2012, Kokubun et al. 2018).

Acknowledgements. We thank Sir Hew Hamilton-Dalrymple and the Scottish Seabird Centre, North Berwick for access to Bass Rock; and Maggie Sheddan, Sam Lowe and the Dale family for logistic support. We thank Ewan Wakefield and Ian Cleasby for help with behavioural classification and calculation of flight heights, and we thank Francis Daunt and 2 anonymous referees for very helpful comments on a previous manuscript. This work was funded by the Natural Environment Research Council (SPHERES DTP; reference NE/ L002574/1), and birds were ringed and loggers deployed with permits and approval from the British Trust for Ornithology. Telemetry data are available free of charge through the BirdLife International Seabird Tracking Database: www. seabirdtracking.org.

\section{LITERATURE CITED}

Albert M, Anguelova MD, Manders AMM, Schaap M, de Leeuw G (2016) Parameterization of oceanic whitecap fraction based on satellite observations. Atmos Chem Phys 16:13725-13751

Amélineau F, Péron C, Lescroël A, Authier M, Provost P, Grémillet D (2014) Windscape and tortuosity shape the flight costs of northern gannets. J Exp Biol 217:876-885

Baptist MJ, Leopold MF (2010) Prey capture success of Sandwich terns Sterna sandvicensis varies non-linearly with water transparency. Ibis 152:815-825

Bartoń K (2015) Mumin: multi-model inference. R package version 1.15.1. http://cran.r-project.org/src/contrib/Archive /MuMIn/

Burnham KP, Anderson DR (2002) Model selection and multimodel inference: a practical information-theoretic approach, $2^{\text {nd }}$ edn. Springer, Berlin

Christensen-Dalsgaard S, May RF, Barrett RT, Langset M, Sandercock BK, Lorentsen SH (2018) Prevailing weather conditions and diet composition affect chick growth and survival in the black-legged kittiwake. Mar Ecol Prog Ser 604:237-249
Cleasby IR, Wakefield ED, Bodey TW, Davies RD and others (2015a) Sexual segregation in a wide-ranging marine predator is a consequence of habitat selection. Mar Ecol Prog Ser 518:1-12

Cleasby IR, Wakefield ED, Bearhop S, Bodey TW, Votier SC, Hamer KC (2015b) Three-dimensional tracking of a wide-ranging marine predator: flight heights and vulnerability to offshore wind farms. J Appl Ecol 52:1474-1482

* Coumou D, Lehmann J, Beckmann J (2015) The weakening summer circulation in the northern hemisphere mid-latitudes. Science 348:324-327

* Dee DP, Uppala SM, Simmons AJ, Berrisford P and others (2011) The ERA-Interim Reanalysis: configuration and performance of the data assimilation system. Q J R Meteorol Soc 137:553-597

* Elliott KH, Chivers LS, Bessey L, Gaston AJ and others (2014) Windscapes shape seabird instantaneous energy costs but adult behavior buffers impact on offspring. Mov Ecol 2:17

Finn J, Carlsson J, Kelly T, Davenport J (2012) Avoidance of headwinds or exploitation of ground effect: Why do birds fly low? J Field Ornithol 83:192-202

Finney SK, Wanless S, Harris MP (1999) The effect of weather conditions on the feeding behaviour of a diving bird, the common guillemot Uria aalge. J Avian Biol 30:23-30

Freckleton RP (2011) Dealing with collinearity in behavioural and ecological data: model averaging and the problems of measurement error. Behav Ecol Sociobiol 65:91-101

Furness RW, Bryant DM (1996) Effect of wind on field metabolic rates of breeding northern fulmars. Ecology 77: 1181-1188

*Gabrielsen GW, Mehlum F, Nagy KA (1987) Daily energy expenditure and energy utilization of free-ranging black-legged kittiwakes. Condor 89:126-132

Gabrielsen GW, Taylor JRE, Konarzewski M, Mehlum F (1991) Field and laboratory metabolism and thermoregulation in dovekies (Alle alle). Auk 108:71-78

* Gibb R, Shoji A, Fayet AL, Perrins CM, Guilford T, Freeman R (2017) Remotely sensed wind predicts soaring behaviour in a wide-ranging pelagic seabird. J R Soc Interface 14:20170262

* Goto Y, Yoda K, Sato K (2017) Asymmetry hidden in birds' tracks reveals wind, heading, and orientation ability over the ocean. Sci Adv 3:e1700097

*Grecian WJ, Lane J, Michelot T, Wade HM, Hamer KC (2018) Understanding the ontogeny of foraging behaviour: insights from combining marine predator bio-logging with satellite-derived oceanography in hidden Markov models. J R Soc Interface 15:20180084

Green M (2004) Flying with the wind - spring migration of Arctic-breeding waders and geese over south Sweden. Ardea 92:145-159

* Grémillet D, Welcker J, Karnovsky NJ, Walkusz W and others (2012) Little auks buffer the impact of current Arctic climate change. Mar Ecol Prog Ser 454:197-206

Grueber CE, Nakagawa S, Laws RJ, Jamieson IG (2011) Multimodel inference in ecology and evolution: challenges and solutions. J Evol Biol 24:699-711

Hamer KC, Phillips RA, Wanless S, Harris MP, Wood AG (2000) Foraging ranges, diets and feeding locations of gannets Morus bassanus in the North Sea: evidence from satellite telemetry. Mar Ecol Prog Ser 200:257-264

* Hamer KC, Phillips RA, Hill JK, Wanless S, Wood AG (2001) Contrasting foraging strategies of gannets Morus bassanus at two North Atlantic colonies: foraging trip duration and 
foraging area fidelity. Mar Ecol Prog Ser 224:283-290

*Hamer KC, Humphreys EM, Garthe S, Hennicke J and others (2007) Annual variation in diets, feeding locations and foraging behaviour of gannets in the North Sea: flexibility, consistency and constraint. Mar Ecol Prog Ser 338:295-305

Hamer KC, Humphreys EM, Magalhães MC, Garthe S and others (2009) Fine-scale foraging behaviour of a mediumranging marine predator. J Anim Ecol 78:880-889

Hernández-Pliego J, Rodriguez C, Dell'Omo G, Bustamente $\mathrm{J}$ (2017) Combined use of tri-axial accelerometers and GPS reveals the flexible foraging strategy of a bird in relation to weather conditions. PLOS ONE 12:e0177892

Kogure Y, Sato K, Watanuki Y, Wanless S, Daunt F (2016) European shags optimize their flight behavior according to wind conditions. J Exp Biol 219:311-318

Kokubun N, Takahashi A, Paredes R, Young RC and others (2018) Inter-annual climate variability affects foraging behavior and nutritional state of thick-billed murres breeding in the southeastern Bering Sea. Mar Ecol Prog Ser 593:195-208

Konarzewski M, Taylor JRE (1989) The influence of weather conditions on growth of little auk Alle alle chicks. Ornis Scand 20:112-116

Krüger T, Garthe S (2001) Flight altitudes of coastal birds in relation to wind direction and speed. Atl Seabirds 3: 203-216

La Sorte F, Fink D (2017) Projected changes in prevailing winds for transatlantic migratory birds under global warming. J Anim Ecol 86:273-284

Lewis S, Benvenuti S, Dall'Antonia L, Griffiths R and others (2002) Sex-specific foraging behaviour in a monomorphic seabird. Proc R Soc B 269:1687-1693

Lewis S, Benvenuti S, Daunt F, Wanless S and others (2004) Partitioning of diving effort in foraging trip of northern gannets. Can J Zool 82:1910-1916

* Lewis S, Phillips RA, Burthe SJ, Wanless S, Daunt F (2015) Contrasting responses of male and female foraging effort to year-round wind conditions. J Anim Ecol 84:1490-1496

* Liechti F, Klaassen M, Bruderer B (2000) Predicting migratory flight altitudes by physiological migration models. Auk 117:205-214

Machovsky-Capuska GE, Howland HC, Raubenheimer D, Vaughn-Hirshorn R, Wursig B, Hauber ME, Katzir G (2012) Visual accommodation and active pursuit of prey underwater in a plunge-diving bird: the Australasian gannet. Proc R Soc B 279:4118-4125

McInnes KL, Erwin TA, Bathols JM (2011) Global climate model projected changes in $10 \mathrm{~m}$ wind speed and direction due to anthropogenic climate change. Atmos Sci Lett 12:325-333

Mullers RHE, Navarro RA, Daan S, Tinbergen JM, Meijer HAJ (2009) Energetic costs of foraging in breeding Cape gannets Morus capensis. Mar Ecol Prog Ser 393:161-171

Parker-Stetter S, Urmy S, Home J, Eisner L, Farley E (2016) Factors affecting summer distributions of Bering Sea forage fish species: assessing competing hypotheses. Deep Sea Res II 134:255-269

Patrick SC, Bearhop S, Grémillet D, Lescroel A and others (2014) Individual differences in searching behaviour and spatial foraging consistency in a central place marine predator. Oikos 123:33-40

Phillips RA, Xavier JC, Croxall JP (2003) Effects of satellite transmitters on albatrosses and petrels. Auk 120: 1082-1090
Pinheiro J, Bates D, DebRoy S, Sarkar D, R Core Team (2018) nlme: linear and nonlinear mixed effects models. R package version 3.1-109. https://cran.r-project.org/package= nlme

* Pistorius PA, Hindell MA, Tremblay Y, Rishworth GM (2015) Weathering a dynamic seascape: influences of wind and rain on a seabird's year-round activity budgets. PLOS ONE 10:e0142623

R Core Team (2016) R: a language and environment for statistical computing. R Foundation for Statistical Computing, Vienna

Kaymond B, Shaffer SA, Sokolov S, Woehler EJ and others (2010) Shearwater foraging in the Southern Ocean: the roles of prey availability and winds. PLOS ONE 5: e10960

Rayner JMV (1991) On the aerodynamics of animal flight in ground effect. Philos Trans R Soc B 334:119-128

Sakamoto KQ, Takahashi A, Iwata T, Yamamoto T, Yamamoto M, Trathan PN (2013) Heart rate and estimated energy expenditure of flapping and gliding in blackbrowed albatrosses. J Exp Biol 216:3175-3182

* Salisbury DJ, Anguelova MD, Brooks IM (2013) On the variability of whitecap fraction using satellite-based observations. J Geophys Res Oceans 118:6201-6222

Schielzeth H (2010) Simple means to improve the interpretability of regression coefficients. Methods Ecol Evol 1:103-113

Shepard E, Cole EL, Neate A, Lempidakis E, Ross A (2019) Wind prevents cliff-breeding birds from accessing nests through loss of flight control. eLife 8:e43842

* Sundarabalan B, Shanmugam P, Ahn YH (2016) Modeling the underwater light field fluctuations in coastal oceanic waters: validation with experimental data. Ocean Sci J 51:67-86

*Tarroux A, Weimerskirch H, Wang SH, Bromwich DH and others (2016) Flexible flight response to challenging wind conditions in a commuting Antarctic seabird: Do you catch the drift? Anim Behav 113:99-112

* Terraube J, Villers A, Poudre L, Varjonen R, Korpimaki E (2017) Increased autumn rainfall disrupts predator-prey interactions in fragmented boreal forests. Glob Change Biol 23:1361-1373

*Villegas-Patraca R, Herrera-Alsina L (2015) Migration of Franklin's gull (Leucophaeus pipixcan) and its variable annual risk from wind power facilities across the Tehuantepec Isthmus. J Nat Conserv 25:72-76

*Wakefield ED, Bodey TW, Bearhop S, Blackburn J and others (2013) Space partitioning without territoriality in gannets. Science 341:68-70

* Wakefield ED, Cleasby I, Bearhop S, Bodey TW and others (2015) Long-term individual foraging site fidelity - why some gannets don't change their spots. Ecology 96: 3058-3074

Weimerskirch H, Louzao M, de Grissac S, Delord K (2012) Changes in wind pattern alter albatross distribution and life-history traits. Science 335:211-214

*Wilson RP, McMahon CR, Quintana F, Frere E, Scolaro A, Hays GC, Bradshaw CJA (2011) N-dimensional animal energetic niches clarify behavioural options in a variable marine environment. J Exp Biol 214:646-656

*YYoung IR, Zieger S, Babanin AV (2011) Global trends in wind speed and wave height. Science 332:451-455

Zuckerberg B, Ribic CA, McCauley LA (2018) Effects of temperature and precipitation on grassland bird nesting success as mediated by patch size. Conserv Biol 32:872-882 